Bartın Üniversitesi

Eğitim Fakültesi Dergisi

Cilt 5, Sayı 2, s. 405-424, Haziran 2016 BARTIN - TÜRKIYE

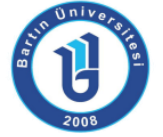

ISSN: 1308-7177
Bartin University

Journal of Faculty of Education

Volume 5, Issue 2, p. 405-424, June 2016

BARTIN - TURKEY

\title{
Fen Öğretiminde Teknoloji Entegrasyonunun 21. Yüzyıl Becerileri Boyutunda Değerlendirilmesi: Yavaş Geçişli Animasyon Uygulaması
}

Nurhan ATALAY, Dr., Eskişehir Osmangazi Üniversitesi, Eğitim Fakültesi, nurratalay@gmail.com

Şengül S. ANAGÜN, Doç. Dr., Eskişehir Osmangazi Üniversitesi, Eğitim Fakültesi, ssanagun@gmail.com

Evrim GENÇ KUMTEPE, Doç. Dr., Anadolu Üniversitesi, Açıköğretim Fakültesi, egkumtepe@anadolu.edu.tr

Öz: Bu çalışmanın amacı sınıf öğretmeni adaylarının yavaş geçişli animasyon (YGA) oluşturma sürecinde 21. yüzyıl becerilerini kullanma durumlarını belirleme ve belirli ölçütlere göre animasyon kullanma yeterliklerinin ortaya konulmasıdır. Araştırmanın çalışma grubunu Türkiye'de Orta Anadolu' da bulunan bir yükseköğretim kurumunun üçüncü sınıfında öğrenimine devam eden 100 öğretmen adayı (16 erkek, 84 kadın) oluşturmaktadır. Araştırmada iç içe geçmiş tekli durum deseni kullanılmıştır. Araştırma verileri araştırmacılar tarafından geliştirilen ve alan uzmanlarınca onaylanan açık uçlu anket formu ve öğrenci ürünleri ile toplanmıştır. Araştırmada nitel veriler öğrencilerden yazııı olarak toplanmış ve betimsel analiz tekniği ile analiz edilmiştir. Araştırma sonucuna göre; öğretmen adaylarının planlama aşamasında "Yaratııılık ve Yenilenme" ile "Girişimcilik ve Öz-yönetim" becerileri dışında 21. yüzyıla ilişkin diğer tüm becerileri kullandıkları belirlenmiştir. Öğretmen adaylarının oluşturdukları animasyonlar belirlenen ölçütlere göre değerlendirildiğinde "Fiziksel Olaylar" öğrenme alanında oluşturulan YGA'ların en yeterli düzeyde olduğu sonucuna ulaşılmışır. Sınıf öğretmeni adaylarının yavaş geçişli animasyon oluşturma sürecinde, 21. yüzyıl becerilerini her aşamada farklı düzeylerde kullandıkları belirlenmiştir. Örneğin, araştırmada, öğretmen adaylarının bilginin farklı kaynaklardan araştııılarak yapılandırıldığı planlama aşamasında "Yaratııılık ve Yenilenme" becerisini kullanmadıkları ancak diğer aşamalarda sınırlı da olsa bu beceriyi kullandıkları sonucuna ulaşılmışır.

Anahtar Kelimeler: Fen öğretimi; teknoloji entegrasyonu; yavaş geçişli animasyon; 21. yüzyıl becerisi; sınıf öğretmeni adayı, durum çalışması

\section{Evaluation of Technology Integration in Science Teaching with 21st Century Skills: A Slowmation Application}

Abstract: The purpose of this study is to determine the status of the use of 21st century skills in the slowmation development process by classroom teacher candidates and to reveal the competencies in using animation based on certain criteria. The participants of the study were 100 junior students (16 males, 84 females) at a mid-western university of Turkey. Embedded single-case design was used in this study. The data were collected through an open-ended questionnaire developed by the authors and validated by the field experts and students' learning artifacts. Qualitative data were collected in a written form and examined through descriptive analysis technique. Results revealed that teacher candidates used most of the 21st century skills in the planning stage of slowmation except for the skills of "Creativity and Innovation" and "Entrepreneurship and Self-Direction". When assessing animations according to the preset criteria, it was concluded that "Physical Events" related slowmation products reflected the most adequate level of understanding. In the slowmation development process, classroom teacher candidates used $21^{\text {st }}$ century skills with different levels at each phase. In the planning phase, for example, teacher candidates have not utilized "Creativity and Innovation" skills to investigate different sources of the structured information even if they have partially used this skill in the other phases.

Key Words: Science teaching; technology integration; slowmation; 21st century skills; classroom teacher candidate, case study 


\section{GíRiş}

Bilgi ve iletişim teknolojileri (BIT)nde yaşanan hızı gelişim, günlük yaşamın her alanında değişim ve dönüşümü beraberinde getirmektedir. Bu değişim ve dönüşüm bireylerin bilgiye daha hızlı ulaşmalarına, ulaştıkları bilgiyi günlük yaşamlarında kullanmalarına, karşılaştıkları birçok probleme alternatif çözümler bulmalarına olanak tanımaktadır. Yaşadığımız yüzyılda, önemli olan bireylerin bilgiye nasıl ulaşacağı değil, ekonomik ve sosyal yaşamında ulaştığı bilgiyi nasıl analiz edip kullanacağıdır. Dolayısıyla 21. yüzyılda, bireylerden beklentiler de değişmektedir (Wagner, 2008). Bireylerden beklenenler sadece bilen değil, sürekli öğrenen, eleştiren, düşünen, sorgulayan, yenilik getiren ve yeniliklere ayak uydurabilen, işbirlikli çalışabilen ve problem çözebilen kısacası 21. yüzyıl becerilerine sahip olmalarıdır (Olkun ve Toluk, 2003).

21. yüzyıl becerileri, yalnız başına ne beceriyi ne de bilgiyi içermektedir. Bu beceriler; anlamayı ve performansı içerir. Başka bir deyişle bilgi ile becerinin harmanlandığı bir kavramdır (Dede, 2010). 21. yüzyıl becerileri; öğrenme ve yenilenme becerileri, yaşam ve kariyer becerileri ve bilgi medya ve teknoloji becerileri olarak üç grupta toplanabilir (Partnership for 21 st Century Skills, 2009). Öğrenme ve yenilenme becerileri boyutunda; problem çözme ve eleştirel düşünme, işbirliği ve iletişim, yaratıcılık ve yenilenme becerileri, yaşam ve kariyer becerileri boyutunda; esneklik ve uyum yeteneği, girişim ve öz yönetim, sosyal ve kültürlerarası beceriler ve liderlik ve sorumluluk, bilgi medya ve teknoloji becerileri boyutunda; bilgi okuryazarlığı, medya okuryazarlığı ve bilgi iletişim ve teknoloji yeterliği olarak tanımlanabilir. $\mathrm{Bu}$ beceriler, öğrencilerin şimdiki ve gelecek sosyal ve çalışma yaşamlarında başarılı olabilmeleri için temel becerilerdir (Partnership for 21 st Century Skills, 2009). Bu nedenle bireylerin bu becerilere sahip olmaları toplumsal gelişim açısından önemlidir. Bireyler 21. Yüzyıl becerilerini ancak eğitim yoluyla edinebilirler. Türkiye'de 2004 yılında uygulamaya konan ilköğretim programlarında tüm derslerde, ortak beceriler olarak eleştirel düşünme, yaratıcı düşünme, iletişim, araştırma, problem çözme, karar verme, bilgi teknolojilerini kullanma, girişimcilik becerilerine yer verilmiştir (MEB, 2004). Bu ortak beceriler, P21 [Partnership for 21 st Century Skills]'in sınıflamasında, bireylerin karmaşık görevleri, düşünmeyi ve iletişimi yerine getirmesini sağlayan yeterlikler bağlamında 21. yüzyıl becerileri olarak adlandırılmaktadır.

Teknolojideki gelişmelerin, birçok uygulama alanı olmasına rağmen en yaygın uygulama alanlarından biri eğitim olduğu için, günümüzde teknoloji alanındaki hızı değişimler teknolojinin eğitimdeki yerini de bu doğrultuda artırmaktadır (Köseoğlu ve diğerleri, 2007; Seferoğlu, Akbıyık ve Bulut, 2008;). Teknolojiyi eğitim ortamına taşıyan ve öğrencilerin teknolojiyi öğrenme öğretme sürecinde etkili bir şekilde kullanabilmesine olanak tanıyan öğretmenlerinde bu yeterliliklere sahip olması gerekmektedir. Öğretmen yetiştiren eğitim kurumlarının temel amacı da, öğrenme ve öğretim sürecinde kullanılan yeni yaklaşımları, teknikleri öğretmen adaylarına öğreterek uygulama sürecinde kendi sınıflarında bu yaklaşımları uygulamalarına olanak tanımaktır (Darling-Hammond, 1995; Hoban, 2005).

Öğretmen adayları, Biт kullanarak "bilimi öğrenmek" veya "bilim yapmak" arasındaki farkı anlayabilirler (Songer, 2007). Son 20 yıldır, üniversitelerde öğretmen adayları sosyal medya (yani wiki ve bloglar), yanı sıra Power-Point, veritabanları ve elektronik tablolar gibi programlar öğretilerek yetiştirilmektedir. Ancak, bu programlar öğretilirken, öğretmen eğitimi programının öğretim yaklaşımlarında bu programların kullanımına yönelik bilgi verilmemekte, öğretmen adayları bu programların sadece öğrenme sürecinde kullanımını öğrenebilmektedirler (Vratulis, Clarke, Hoban ve Erickson, 2011). Teknolojinin eğitime farklı yönlerden entegrasyonu değişik öğrenme öğretme yaklaşımlarını da ortaya çıkarmıştır. Özellikle fen öğretiminde kullanılan etkili öğrenme öğretme yaklaşımlarından birisi de yavaş geçişli animasyonlardır (Keast ,Cooper, Berry, Loughran ve Hoban, 2010). Animasyonlar, Fen 
Bilimleri dersinde gerçekleşen olayların öğrencilerin zihninde canlandırılabilmesinde, soyut bilgilerin somut kavramlar olarak şekillenmesine yardımcı olabilir (Atılboz, 2004). Animasyon; Ingilizcesi "animation" aslında "canlandırma" anlamında kullanılmasına rağmen Türkçe cümleler içerisinde de kullanılırken kendisine bir anlam kazandırmıştır. Türk Dil Kurumu animasyonu "tek tek resimleri veya hareketsiz cisimleri gösterim sırasında hareket duygusu verebilecek bir biçimde düzenleyerek filme aktarma işi" olarak tanımlamaktadır (Ekici ve Ekici, 2011). Yavaş geçişli animasyon (slowmation) ise slow (yavaş) ve animation (animasyon) kavramlarından türemiş bir kavramdır (Hoban ve Nielsen, 2010).

Yavaş geçişli animasyon (slowmation) oluşturma süreci, ilk olarak modellerin yapılması daha sonra bir animasyon efekti elde etmek için modellerin küçük sıralı hareketlerini gösteren dijital fotoğrafların oluşturulması ve bu fotoğrafların dijital video programına yerleştirilmesi ile tamamlanır (Kervin, 2007). Yavaş Geçişli Animasyon, animasyon hazırlamanın karmaşık sürecini basitleştirerek, ilkokul ve ortaokul öğrencilerine fen kavramları hakkında kendi kapsamlı animasyonlarını hazırlamaları için olanak sağlar (Hoban, 2005, Hoban ve Ferry, 2006, Hoban, 2007 ve Hoban, 2009). Yavaş geçişli animasyonun en önemli özelliği de bilgisayar animasyonu gibi saniyede 24 kare değil de 2 karenin yer almasıdır. Çünkü burada amacımız bir öykü ya da hikâye sunmak değil yavaş yavaş bilimsel bir kavramı göstermek ve açıklamaktır (Hoban, 2007). Yavaş geçişli animasyon, dijital teknikle çekilmiş her biri elle kontrol edilmiş model fotoğrafların hareketlendir-durdur tekniğiyle oluşturulmasıdır (Laybourne, 1998). Yavaş geçişli animasyon, öğrenenlerin değişimleri içeren kavram veya konuyu nasıl sunacaklarını araştırdıkları ve görev paylaşımının yapıldığı planlama aşaması; araştırılmış, seçilmiş ve geliştirilmiş konuyu destekleyen hikâyelerin oluşturulduğu hikâyeleştirme aşaması; modellerin yapıldığı ve fotoğraflandığı oluşturma aşaması; dijital fotoğrafların bilgisayara yüklenerek bir sıraya konulduğu ve bilgisayar programına aktarılıp animasyona dönüştürüldüğg̈ yeniden oluşturma aşaması olmak üzere dört aşamadan oluşur (Hoban, 2007).

Yavaş geçişli animasyonların öğrenme öğretme sürecine etkisinin araştırıldığı çalışmalarda, öğrencilerde bilim okuryazarlığına, 21. yüzyıl öğrenen özeliklerinin kazandırılması bağlamında katkı sağladığı, derse karşı olumlu tutum geliştirdiği, fen kavramlarının öğretiminde ve kavramsal becerilerin geliştirilmesine etkisinin olduğu belirlenmiştir (Brown, 2011; Czarnecki 2009; Oshner, 2010). Ayrıca bilişim teknolojilerinin avantajlarından faydalanmayı ve eğitim ortamlarında yapılandırmacı felsefe bağlamında öğrencileri merkeze alarak öğrenmelerini kolaylaştırmayı isteyen eğitimciler için pratik bir etkinlik olarak önerilmiştir (Ekici ve Ekici, 2011). Yurt dışında yavaş geçişli animasyonun öğrenme-öğretme sürecine kullanımı, oluşturulması ve etkilerine ilişkin araştırmalar olmasına karşın bu konuda ülkemizde bu yaklaşımın kullanıldığı bir çalışmaya rastlanmamıştır. Bu çalışmanın amacı; yavaş geçişli animasyonların oluşturulma sürecinde öğretmen adayları tarafından 21. yüzyıl becerilerinin farklı boyutlarının (öğrenme ve yenilenme becerileri, yaşam ve kariyer becerileri, bilgi medya ve teknoloji becerileri) kullanılma durumlarının ve belirlenen ölçütlere göre animasyonların yeterliklerinin ortaya konulmasıdır. Araştırmada aşağıdaki alt problemlere yanıt aranmaktadır:

1. Yavaş geçişli animasyon oluşturma sürecinin planlama hikâyeleştirme oluşturma ve yeniden oluşturma aşamasında 21. yüzyıl becerilerinin kullanılma durumu nasıldır?

2. Oluşturulan yavaş geçişli animasyonların (YGA), ölçüt olarak kabul edilen analitik dereceli puanlama anahtarına göre yeterlikleri nasıldır? 


\section{YÖNTEM}

\subsection{Araştırma Modeli}

Araştırmada, nitel araştırma yöntemlerinden durum çalışmasına yer verilerek "iç içe geçmiş tekli durum" deseni kullanılış̧tır. Tek durum, içinde birden fazla alt tabaka ya da analiz biriminin bulunduğu durumlarda iç içe geçmiş tekli durum deseni kullanılmaktadır (Yıldırım ve Şimşek, 2005). Durum çalışması, nitel araştırma şemsiyesi altındaki araştırma türlerinden biridir. Durum çalışmaları farklı amaçlarla yapııı (Gall, Gall ve Borg, 1999, s.289-290; Akt: Ersoy, 2006, s.68-69). Durum çalışmaları güncel bir olgunun gerçek yaşam bağlamında araştırılmasında ve olgu ile bağlam arasında belirgin çizgilerin belirlenemediği durumlarda olgu ile bağlam arasındaki örüntüleri ayrıntılı bir biçimde derinlemesine belirleyebilmek için kullanılır (Yin, 2003, s. 13). Bu çalışmada da araştırılacak durum, Fen ve Teknoloji Öğretimi II dersi bağlamında uygulanan yavaş geçişli animasyon uygulamasının 21. yüzyıl becerilerinin kullanımı bakımından işlevselliğinin ayrıntılı bir biçimde ortaya konulmasıdır.

\subsection{Katılımcılar}

Araştırma katılımcıları, nitel araştırma geleneğinde gelişen amaçlı örnekleme türlerinden ölçüt örnekleme ile seçilmiştir. Bu örnekleme yönteminde katılımcıların belirlenmesinde araştırmacıların belirleyeceği ölçütler kullanılabileceği gibi önceden belirlenmiş bir ölçüt listesi de kullanılabilir (Yıldırım ve Şimşek, 2005, s.112). Bu araştırmada iki temel ölçüt belirlenmiştir. Bu ölçütler, 1) araştırmaya gönüllü katılma ve 2) Sınıf öğretmenliği programında, fen ve teknoloji laboratuvarı ve diğer temel fen derslerinin alınarak tamamlandığı dikkate alındığında öğretmen adaylarının sınıf öğretmenliği üçüncü sınıfa devam ediyor olmaları temel alınmıştır. Çalışmaya Orta Anadolu'da bir eğitim fakültesinin üçüncü sınıfına devam eden 16' sı erkek 84' ü kadın 100 öğretmen adayı katılmıştır.

\subsection{Veri Toplama Araçları}

Araştırma verileri, açık uçlu sorulardan oluşan anket formu ve öğrenci ürünleri (YGA) ile toplanmıştır.

\subsection{Uygulama Süreci}

Uygulama, Sınıf Öğretmeni adayları ile Fen ve Teknoloji Öğretimi II dersi kapsamında toplam on haftada gerçekleştirilmiştir. Uygulama öncesinde, araştırmacılar tarafından altı ders saati sürecince yavaş geçişli animasyon oluşturma sürecine ve bu süreçte kullanılan Movie Maker programı hakkında bilgilendirilme yapılmıştır. Öğrenciler kendi isteklerine göre 4-5 kişiden oluşan gruplar oluşturmuşlardır. Her bir grup ilköğretim Fen Bilimleri öğretim programında yer alan "canlılar ve hayat", "madde ve değişim", "fiziksel olaylar", "dünya ve evren" öğrenme alanlarının birinden kendi çalışma konusunu belirleyerek toplam 24 YGA oluşturmuşlardır. Öğrenme alanlarına göre belirlenen konular aşağıdaki gibidir: 
Tablo1

Öğrenme Alanlarına Göre Belirlenen Konular

\begin{tabular}{|c|c|c|c|}
\hline Canlılar ve Hayat & Madde ve Değişim & Fiziksel Olaylar & Dünya ve Evren \\
\hline $\begin{array}{ll}\text { - } & \text { Çimlenme (1) } \\
\text { - } & \text { Canlıların Yaşam } \\
& \text { Döngüsü(1) } \\
\text { - } & \text { Kelebeğin Yaşam } \\
& \text { Döngüsü(1) } \\
\text { - } & \text { Mayalanma(2) } \\
\text { - } & \text { Mayoz Bölünme(1) } \\
\text { - } & \text { Mitoz Bölünme(1) } \\
\text { - } & \text { Su Döngüsü(1) }\end{array}$ & $\begin{array}{l}\text { - Maddenin Hal Değişimi(2) } \\
\text { - Karışımları Ayırma (2) } \\
\text { - Geri Dönüşüm (1) }\end{array}$ & $\begin{array}{l}\text { - Elektriklenme (2) } \\
\text { - Şimşek ve Yıldırım(1) }\end{array}$ & $\begin{array}{l}\text { - Ayın Evreleri (3) } \\
\text { - Gece ve } \\
\text { Gündüz } \\
\text { Oluşumu (2) } \\
\text { - Güneş } \\
\text { Tutulması(1) } \\
\text { - Mevsimlerin } \\
\text { Oluşumu(2) }\end{array}$ \\
\hline
\end{tabular}

Belirlenen konular çerçevesinde ve araştırmacıların rehberliğinde, YGA oluşturma sürecinde yer alan her aşamaya iki hafta verilerek toplam sekiz haftada YGA' lar yapılandırılmıştır.

Planlama; bu aşamada grup üyeleri bir araya gelerek ilgili konuyu nasıl animasyon haline dönüştürecekleri ile ilgili fikir alışverişinde bulundular. Konu ile ilgili bilgilere değişik kaynaklardan ulaşmaya çalıştılar. Hangi materyallerle çalışmaları gerektiğine karar verdiler. Konunun içeriğine ve anlatım kolaylığına, iki boyutlu ya da üç boyutlu anlatma durumuna göre oyun hamuru, karton, pamuk, vb. materyaller seçildi. Bu materyallerin temini ve bilgi toplanması konusunda iş bölümü yapıldı.

Hikâyeleştirme; oluşturulan içerik, konunun daha iyi aktarılması için birkaç bölüme ayrıldı. Her bölümdeki ilgili parçalar canlandırmayı daha iyi sağlamak için hikâye 10-20 parçaya bölündü.

Oluşturma; bu aşamada canlandırmayı sağlamak için kararlaştırılmış modeller oluşturuldu. Oluşturulan modeller genellikle profesyonel fotoğraf makinesi kullanılarak fotoğrafları çekildi. Fotoğrafların kaymasını önlemek için tripot kullanıldı. Anlatılmak istenen konuya göre ortalama 500-800 fotoğraf çekildi. Aşağıda çekilen fotoğraf örnekleri yer almaktadır.

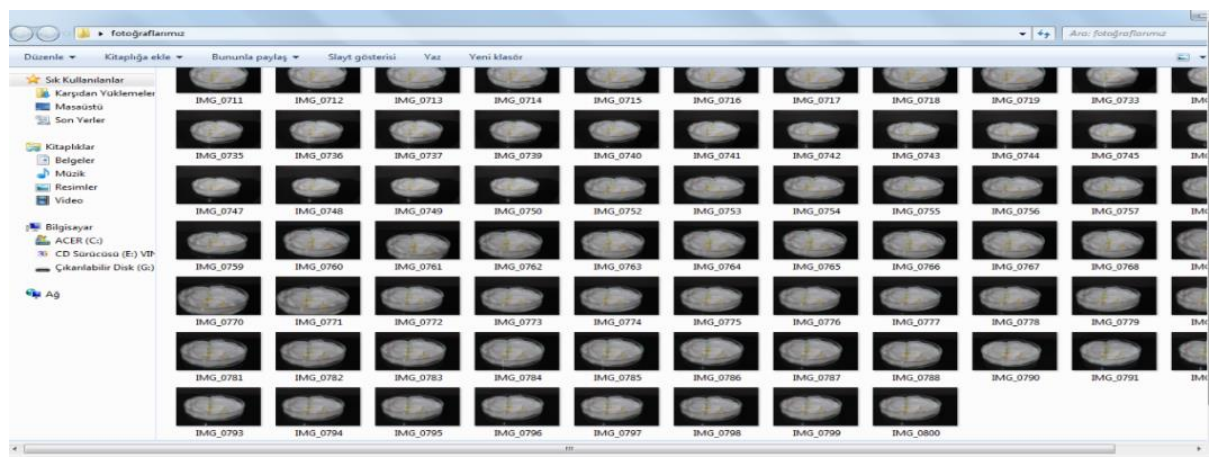

Şekil 1. "Çimlenme" Konusuna İlişkin Fotoğraf Klasörü 


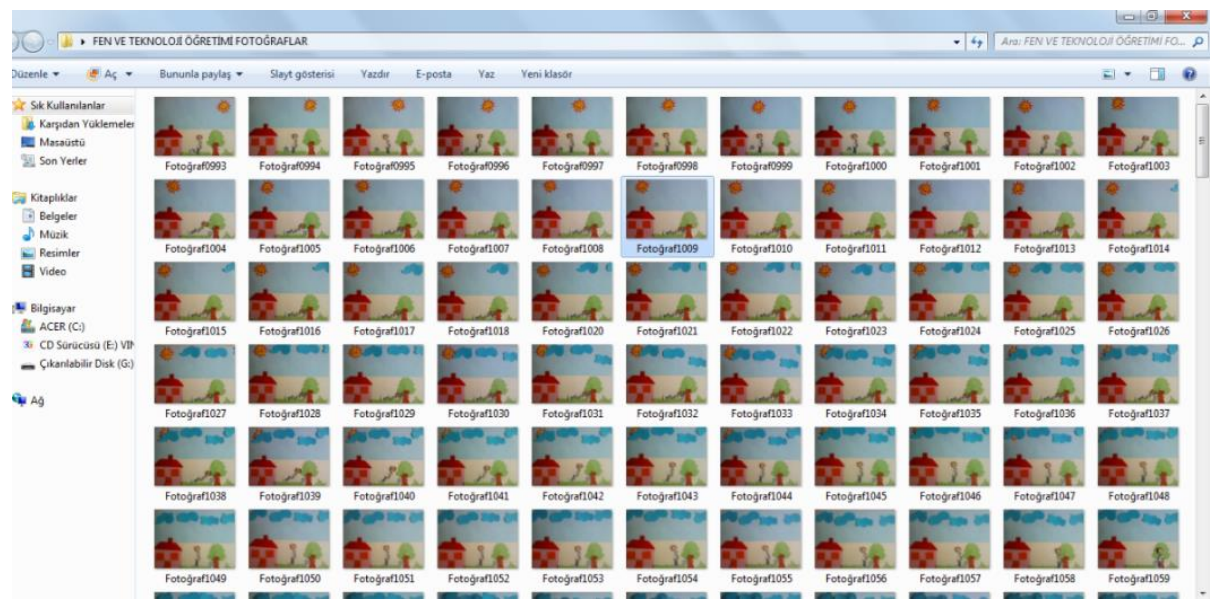

Şekil 2. "Yıldırım ve Şimşek Oluşumu" Konusuna İlişkin Fotoğraf Klasörü

Yeniden Oluşturma; elde edilen fotoğraflar oluşturulan kurguya göre sıralanıp bilgisayarda bir klasöre kaydedildi. Daha sonra animasyonumuzu oluşturan Windows Movie Maker programı açılıp fotoğraflar bu programa aktarıldı. Fotoğraflar arası geçiş süreleri belirlendi. Daha sonra animasyona eklenecek müzik, başlık ve diğer videolar gibi kısımlar eklendi. Son olarak animasyon kaydedilerek süreç tamamlanmıştır.

\subsection{Verilerin Analizi}

Araştırmada, betimsel analiz tekniğinden yararlanılmıştır. Betimsel analiz, araştırma konusuna ilişkin alan yazında kavramsal ve kuramsal olarak yeterli açıklamanın olduğu durumlarda kullanılmaktadır. Bu analizde, veriler, daha önceden belirlenen temalara göre özetlenir ve yorumlanır. (Yıldııım ve Şimsek, 2005, s.224). Öğrencilerin YGA oluşturma sürecinin her aşamasında kullandıkları beceriler; öğrenme ve yenilenme becerisi (yaratıcılık ve yenilenme, eleştirel düşünme ve problem çözme, iletişim ve işbirliği), yaşam ve kariyer becerisi (esneklik ve uyum yeteneği, girişimcilik ve özyönetim, sosyal ve kültürlerarası beceriler ve liderlik ve sorumluluk) alt boyutlarında, bilgi medya ve teknoloji becerisi (bilgi okuryazarlığı, medya okuryazarlığı ve bilgi ve iletişim teknolojileri yeterliği) alt boyutlarında analiz edilmiştir.

Öğrencilerin ürünleri (YGA)’ lar Atalay (2015) tarafından geliştirilen analitik dereceli puanlama anahtarı kullanılarak analiz edilmiştir. Grupların aldıkları ortalama puanlar üzerinden YGA'ların yeterlik durumları düşük, orta ve yüksek düzey olarak değerlendirilmiştir. YGA oluşturma aşamalarını temel alarak oluşturulan analitik dereceli puanlama anahtarı Tablo 2'de verilmiştir.

Tablo 2

Dereceli Puanlama Anahtarı

\begin{tabular}{ll}
\hline Puan & Planlama (\%25) \\
\hline & - Anlatılmak istenilen, merak edilen konu ile ilgili kavramlar ve içerik farklı \\
& kaynaklardan detaylı bir biçimde araştırılmıştır. ( 1 puan) \\
- & Bilgi paylaşımında bulunulmuştur. (1 puan) \\
- Grup üyeleri konuyu nasıl daha iyi aktarabilecekleri, nasıl animasyon haline \\
dönüştürebilecekleri ve sürece ilişkin fikir alışverişinde bulunulmuştur. (1 puan) \\
- Animasyonda hangi tür materyallerin kullanılacağına ilişkin karar, grup üyeleri \\
tarafından ortaklaşa alınmıştır. ( 1 puan) \\
- Grup üyeleri arasında (roller, resimli hikâyeci, model yapıcı, senaryo yazıcı,
\end{tabular}




\begin{tabular}{|c|c|}
\hline & fotoğrafçı ve arka plan tasarımcısı) iş bölümü yapılmıştır. (1 puan) \\
\hline & Hikâyeleştirme (\%25) \\
\hline \multirow{6}{*}{5 puan } & - Oluşturulan içerik (hikâye) , konunun daha iyi aktarılması için birkaç bölüme \\
\hline & $\begin{array}{l}\text { - Canlandırmayı daha iyi gerçekleştirmek için her bölüm 10-20 parçaya } \\
\text { bölünmüştür. (1 puan) }\end{array}$ \\
\hline & $\begin{array}{l}\text { - Anlatılmak istenilen konu ile ilgili kavramlar hikâyede net bir biçimde anlatılmıştır. } \\
\text { (1 puan) }\end{array}$ \\
\hline & - Hikâyenin belli bir akışı (giriş, gelişme, sonuç ) vardır. (1 puan) \\
\hline & - Araştırılan bilgiler hikâyeye çok bir şekilde bütünleşmiş edilmiştir (1puan). \\
\hline & Oluşturma (\%25) \\
\hline \multirow{6}{*}{5 puan } & $\begin{array}{l}\text { - Her bölümde canlandırmayı sağlamak için hikâyeye uygun modeller } \\
\text { oluşturulmuştur. ( } 1 \text { puan) }\end{array}$ \\
\hline & $\begin{array}{l}\text { - Modellerin tek boyut, } 2 \text { boyutlu ya da üç boyutlu olmaları konusunda hikâyeye } \\
\text { uygun davranılmıştır. ( } 1 \text { puan) }\end{array}$ \\
\hline & $\begin{array}{l}\text { - Oluşturulmak istenilen modeller, uygun materyaller kullanılarak oluşturulmuştur. } \\
\text { (1 puan) }\end{array}$ \\
\hline & $\begin{array}{l}\text { - Modellere çok küçük hareketler verilerek her bir hareket sabit bir biçimde } \\
\text { fotoğraflandırılmıştır. ( } 1 \text { puan) }\end{array}$ \\
\hline & - Fotoğraflama işlemi hikâyeye uygun bir biçimde yapılmıştır (1 puan) \\
\hline & Yeniden Oluştuma (\%25) \\
\hline \multirow{5}{*}{5 puan } & $\begin{array}{l}\text { - Windows Movie Maker veya ilgili başka bir program etkili bir biçimde } \\
\text { kullanılmıştır. (1 puan) }\end{array}$ \\
\hline & - Elde edilen fotoğraflar oluşturulan kurguya (hikâyeye ) göre sıralanmıştır. (1 puan) \\
\hline & $\begin{array}{l}\text { - Fotoğraflar arasındaki geçiş süreleri ve hikâyenin sesli kullanımı birbiriyle } \\
\text { örtüşmektedir. (1 puan) }\end{array}$ \\
\hline & $\begin{array}{l}\text { - Animasyonu zenginleştirecek olan ( video, efektler, başlık ...)eklentiler } \\
\text { kullanılmıştır. (1 puan) }\end{array}$ \\
\hline & $\begin{array}{l}\text { Eklentiler eklendikten sonra animasyona son hali verilip grup üyelerince } \\
\text { sunulmuştur. (1 puan). }\end{array}$ \\
\hline
\end{tabular}

Araştırmada kullanılan dereceli puanlama anahtarın güvenirliği, Miles ve Huberman (1994) tarafından önerilen güvenirlik (uyuşum yüzdesi)= [görüşbirliği /(görüş ayrılığı + görüş birliği)] x 100 formülüne göre 0.92 olarak hesaplanmıştır

\section{BULGULAR}

Fen Bilimleri dersinde gruplara ayrılan öğrenciler, belirledikleri konuların kazanımlarını göz önünde bulundurularak planlama, hikâyeleştirme, oluşturma ve yeniden oluşturma aşamalarını da uygulanarak YGA'ları oluşturmuşlardır. Bu bölümde, araştırmanın alt amaçları doğrultusunda veri toplama araçları ile elde edilen verilerin analizi ile ulaşılan bulgular ve bu bulgular doğrultusunda yapılan yorumlara yer verilmiştir.

\section{1. Öğretmen adaylarının YGA'ları oluşturma sürecinde kullandıkları 21. yüzyıl becerilerine ilişkin bulgular}

Öğretmen adaylarının YGA'ları oluşturma sürecinde kullandıkları 21. yüzyıl becerileri ( Öğrenme ve Yenilenme, Yaşam ve Kariyer Becerileri ve Bilgi Medya ve Teknoloji Becerileri) Tablo 3' te gösterilmiştir. 
Fen Öğretiminde Teknoloji Entegrasyonunun 21. Yüzyıl Becerileri Boyutunda Değerlendirilmesi: Yavaş Geçişli Animasyon Uygulaması

Nurhan ATALAY - Şengül S. ANAGÜN - Evrim GENÇ KUMTEPE

Tablo 3

Öğretmen Adaylarının Yavaş geçişli Animasyon (YGA) Oluşturma Sürecinde Kullandıkları 21. Yüzyıl Becerileri

\begin{tabular}{|c|c|c|c|c|c|c|c|c|c|c|}
\hline \multirow[t]{2}{*}{ YGA Aşamaları } & \multicolumn{3}{|c|}{$\begin{array}{c}\text { Öğrenme ve Yenilenme } \\
\text { Becerileri }\end{array}$} & \multicolumn{4}{|c|}{$\begin{array}{c}\text { Yaşam ve Kariyer } \\
\text { Becerileri }\end{array}$} & \multicolumn{3}{|c|}{$\begin{array}{c}\text { Bilgi Medya ve } \\
\text { Teknoloji Becerileri }\end{array}$} \\
\hline & 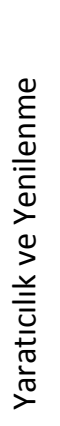 & 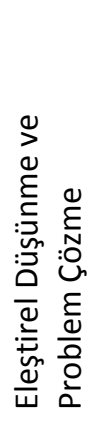 & 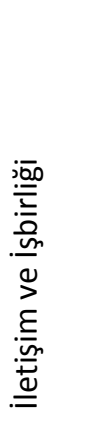 & 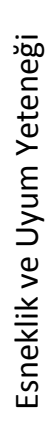 & 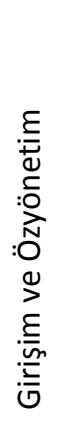 & 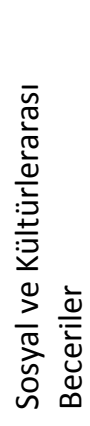 & 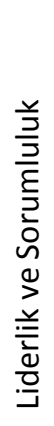 & 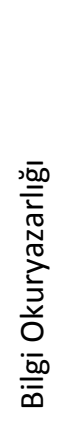 & 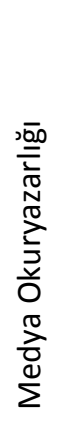 & 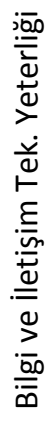 \\
\hline Planlama & - & V & V & $\sqrt{ }$ & - & $\checkmark$ & $\sqrt{ }$ & $\mathrm{V}$ & $\sqrt{ }$ & $\sqrt{ }$ \\
\hline Hikâyeleştirme & $\checkmark$ & V & $\sqrt{ }$ & $\sqrt{ }$ & $\sqrt{ }$ & - & - & 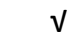 & $v$ & 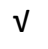 \\
\hline Oluşturma & $\checkmark$ & V & V & - & $\sqrt{ }$ & - & - & 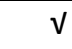 & $\sqrt{ }$ & $\mathrm{V}$ \\
\hline $\begin{array}{l}\text { Yeniden } \\
\text { Oluşturma }\end{array}$ & V & $\mathrm{V}$ & V & - & - & - & - & - & - & $\mathrm{V}$ \\
\hline
\end{tabular}

Tablo 3 incelendiğinde, öğretmen adaylarının seçtikleri konulara yönelik araştırma yaptıkları ve görev paylaşımının yapıldığı planlama aşamasında, yaratıcılık ve yenilenme becerisini kullanmadıkları ancak süreçte eleştirel düşünme problem çözme ve işbirliği iletişim becerilerini kullandıkları belirlenmiştir. Planlama aşamasında öğretmen adaylarının esneklik ve uyum yeteneğini gösterdikleri, sosyal ve kültürlerarası becerileri işe koştukları belirlenmiştir. Yine bu aşamada öğrencilerin farklı kaynaklardan edindikleri bilgileri kendilerine göre içselleştirdiği, medya araçlarındaki kullanımları kendilerine göre ifade ettikleri ve farklı dijital araçları kullandıkları belirlenmiştir. Bu bağlamda öğretmen adaylarının bilgi okuryazarlığı, medya okuryazarlığı ve bilgi ve iletişim teknoloji yeterliği becerisini bu aşamada kullandıkları görülmektedir. Planlama aşamasında gruplardan G3 "Öğrencinin yaşını anlatmak istediğimiz olayın vermek istediğimiz mesajı senaryoya nasıl aktarabileceğimizi düşündük. Önümüze çıkan problemlerde neler yapabileceğimizi tartışarak bir sonuca vardık.", G13 "Elektriklenme konusuna ilgi çekmek ve güdülemek için çizgi film karakterlerinden faydalanmaya karar verdik.". biçiminde görüş bildirerek eleştirel düşünme ve problem çözme becerilerini kullandıklarını belirtmişlerdir.

Oluşturulan gruplardan G8 "Kullanacağımız yöntem ve malzemelere karar vermek için fikirlerimizi birbirimizle sözlü ve görsel olarak paylaştık.", G24 "Fikir ve bilgilerimizi öncelikle görsel olarak ifade ettik ve fikir alışverişinde herkesin fikrini dinledik." biçiminde görüş bildirerek planlama aşamasında iletişim ve işbirliği becerilerini kullandıklarını belirtmişlerdir. Öğrencilerin planlama aşamasında "Yaşam ve Kariyer Becerilerini" çok fazla kullanmadıkları belirlenmiştir. Gruplardan sadece üç tanesinin planlama aşamasında "Esneklik ve Uyum" becerilerini kullandıkları belirlenmiştir. Gruplarda G10 uyum içinde çalıştıklarını "Grup üyelerinin farkı fen bilgisi altyapısı ve becerileri deneyimleri bakış açıları algıları ve yorumları animasyon etkinliğimizin her basamağında olumlu sonuçlar doğurmuştur." biçiminde görüş bildirerek belirtmiştir. 
Planlama aşamasında öğretmen adaylarının "Girişim ve Öz Yönetim becerilerini" kullanmadıkları görülürken, iki grupta bulunan öğrencilerin "Sosyal ve kültürlerarası becerilerini" kullandıkları belirlenmiştir. Bu beceriyi işe koşan gruplardan G7 "Bu konuda diğer grup arkadaşlarımızla görüşmeler yaptık. Aynı konu üzerine yapılan farklı etkinlikleri görmüş olduk. Uygulama aşamasında ne tür kaynak ve malzemeden yararlandıklarını sorarak iletişimde bulunduk." biçiminde görüşünü belirtmiştir. Öğretmen adaylarının oluşturduğu gruplardan G11 "Grup üyeleri arasında görev paylaşımı yapıldı ve herkes üzerine düşeni yapmaya gayret gösterdi." biçiminde görüş bildirerek "Liderlik ve Sorumluluk" becerisini kullandıklarını belirtmiştir.

Planlama aşamasında grupların tamamıma yakınının hem bilgi ediniminde hem de animasyona ilişkin örnekler bulma konusunda Bilgi Medya ve Teknoloji Okuryazarlığı becerisini işe koştuklarını ifade etmişlerdir. Gruplardan G3 "Öncelikle konumuzda ilgili internetten bilgiler topladık ve bu bilgilerden çıkarımlar yaparak bir plan oluşturduk.", G23 "Önce su döngüsüyle ilgili olarak bilimsel bilgileri araştırdık yapılan ürünleri inceledik. Daha sonra bu bilgileri nasıl uygulayacağımızı planladık." biçiminde görüş bildirerek "Bilgi okuryazarlı̆̆ı" becerisini kullandıklarını belirtmişlerdir. Grupların tamamına yakınının bilgiye etkili bir biçimde ulaştığı belirlenmiştir. Öğretmen adaylarının sınılı düzeyde kullandıkları "Medya Okuryazarlığı" becerisine yönelik G5 "Animasyonumuzda kullanacağımı mayalanma ile ilgili bazı şeyleri reklamlarda gördügüüüz gibi yapalım dedik ama sonra çok kısa olur diye en baştan anlattık." biçiminde görüş belirtmiştir. Oluşturulan gruplardan G4 "Bilgilere ulaşmak için internetteki kaynakları ve e-kütüphaneyi kullandık.", G12 "Elektriklenme konusu işlenirken vikipedia sitesinden yararlandık." biçiminde görüş bildirerek "Bilgi ve Illetişim Teknolojileri Yeterliği" becerisini kullandıklarını belirtmişlerdir.

Tablo 3' e göre öğretmen adaylarının araştırdıkları konuları senaryoya haline getirdikleri ve aşama aşama resim halinde çizdikleri hikâyeleştirme aşamasında, ağırlıklı olarak işbirliği ve iletişim becerisini işe koşarken yaratıcılık ve yenilenme, eleştirel düşünme problem çözme becerilerini de kullandıkları belirlenmiştir. Yine bu aşamada öğretmen adaylarının esneklik ve uyum yetenekleri ile girişimcilik özelliklerini işe koştukları, aynı zamanda bilgi ve iletişim teknolojilerine ilişkin yeteneklerini kullandıkları belirlenmiştir. Gruplardan 13'ünde görev alan öğretmen adaylarının animasyonun hikâyeleştirme aşamasında 21. yüzyı öğrenme ve yenilenme becerilerinin alt boyutlarından "yaratıcılık ve yenilenme becerisi "ni kullandıkları belirlenmiştir. Gruplardan G3 "Ayrıca tüm hikâye boyunca da kendimize özgü bir hikâye oluşturarak yaratıcılığımızı sonuna kadar kullandık.", "G24 "Hikâyemizi oluştururken yalnızca yıldırım ve şimşek oluşumunu göstermek amacında değildik, bunu eğlenceli ve çocukların yaşamına yakın, ilgi çekici ve farklı bir hikâye şeklinde oluşturduk. " biçiminde görüş bildirerek yaratıcılık ve yenilenme becerilerini kullandıklarını belirtmişlerdir.

Gruplardan 14'ünde görev alan öğretmen adaylarının animasyonun hikâyeleştirme aşamasında genel anlamda eleştirel düşünme ve problem çözme becerilerini kullandıklarını ifade etmişlerdir. Gruplardan G4 "Hikâyeyi oluştururken geri dönüşüm çöp atık gibi konularda meydana gelen sorunlar ve çözümler gündeme getirilip taslak bir kurmaca oluşturuldu. Internet üzerinden araştırdığımız olay örgülerini ve kendi oluşturduğumuz hikâyeyi gözden geçirdik ve karar verdik." biçiminde görüş bildirmiştir. Gruplardan 19'unda görev alan öğretmen adaylarının animasyonun hikâyeleştirme aşamasında genel anlamda iletişim ve işbirliği becerilerini kullandıklarını ifade etmişlerdir. Gruplardan G10 "Hepimiz hikâyenin oluşumu konusunda bilgi verdik isteklerimizi paylaştık ve ortak bir sonuca vardık. " biçiminde görüş bildirmiştir.

Gruplardan dördü olumlu anlamda uyum içinde çalışabildiklerini, kendilerine verilen görevleri verimli bir biçimde yerine getirdiklerini ve verilen sorumluluklara uyum sağladıklarını 
belirtmiştir. Gruplardan G15 "Fikirlerimizi birbirimize açıkça ifade ettik. Fikir çatışmaları yaşandı ama ortak bir karara varılarak hikâyemiz tamamlandı.", G20 "Herkes kendi fikrini söyledi. Beğenmediğimiz ya da daha iyisini yapabileceğimiz fikirleri eleştirdik daha fazla ne yapabiliriz onu düşündük. Herkes üzerine düşen görevi yerine getirdi." biçiminde görüş belirtmiştir. Gruplardan ikisinde görev alan öğretmen adayları animasyonun hikâyeleştirme aşamasında girişimcilik ve öz-yönelim becerilerini kullandıklarını ifade etmişlerdir. Gruplardan G7 “ Hikâyeleştirme aşamasında herkes üzerine düşeni yerine getirdiği için iş bölümü başarılı bir biçimde sonuçlandı. Konumuzu en güzel bir biçimde anlatacak hikâyeyi yazmak için üstün bir performans sergilediğimizi düşünüyoruz." biçiminde görüş bildirmiştir.

Öğretmen adaylarının hikâyeleştirme aşamasında "sosyal ve kültürlerarası beceriler" ve "liderlik ve sorumluluk" becerilerini kullandıklarını gösteren ifadeler kullanmadıkları belirlenmiştir. Gruplardan üçünde yer alan öğretmen adaylarının hikâyeleştirme aşamasında bilgi eksikliğini hissettikleri bölümlerde farklı kaynaklara yönelerek "bilgi okuryazarlığı" becerilerini işe koştukları görülmektedir. Gruplardan G12 "Hikâyemizi yazarken bulduğumuz bilgilerin farklı olduğunu gördük. O yüzden tekrar farklı kaynaklara bakmak zorunda kaldık. Aslında biraz daha araştırmak iyi oldu. En doğru bilgiye ulaştık". G 14 "Bilimsel bilgi olarak buğdayın çimlenme sürecini ve hangi ortamda hangi sıcaklıkta yetiştiğini araştırdık." biçiminde görüş bildirmişlerdir. Medya okuryazarlılığı bağlamında, iki grupta bulunan öğrencilerin medya kaynaklarından kendi amaçlarına hizmet edecek bölümleri örnek aldıklarını ifade etmişlerdir. Gruplardan G8 "Farklı animasyonları izleyip hikâyemizi nasıl yazacağımıza karar verdik. Konuyu nasıl hikâyeye dönüştüreceğimize böyle karar verdik aslında" biçiminde görüş bildirmiştir. Gruplardan tamamına yakınının, görsellerin elde edilmesinde, örnek animasyonların ve hikâyelerin araştırılmasında ve içeriği zenginleştirme için bilgi ve iletişim teknolojilerini kullandıkları söylenebilir. Gruplardan G1 "Slowmation uygulaması konusunda çeşitli forum siteleri ziyaret edilerek yorumlar okundu. Bu aşamada çeşitli slowmationlar izlenerek fikir sahibi olundu" G16 "Hikâyeleştirirken you tube adlı internet sitesinden güneş tutulması ile ilgili birçok video izledik" biçiminde görüş bildirmişlerdir.

Tablo 3 incelendiğinde, öğretmen adaylarının hikâyelerine uygun modelleri oluşturdukları ve fotoğraf çekimlerini yaptıkları oluşturma aşamasında esneklik ve uyum, sosyal ve kültürlerarası beceriler ile liderlik ve sorumluluk becerilerini kullanmadıkları belirlenmiştir. Ancak 21. yüzyıla yönelik diğer becerileri süreç boyunca kullandıkları görülmüştür. Oluşturulan gruplardan $21^{\prime} \mathrm{i}$ animasyonun oluşturma aşamasında genel anlamda yaratıcılıklarını kullandıklarını ifade etmişlerdir. Gruplardan G3 "Sahnede kullandığımız her bir nesneyi oluştururken grup üyelerinin farklı fikirlerini bir araya getirdik ve böylece orijinal farklı ürünler elde etik. Fotoğraf çekme aşamasında ise ışığı farklı açılardan ayarlarken yaratıcığımızı kullanarak ışığın resim üzerinde ne gibi etkisi olduğu ayarlayarak resimlerimizi çektik". G15 "Önce hamurdan yapmayı denedik. Ay modeli fotoğraflarda güzel görünmediği için başka bir fikir ürettik. Kartondan yapmayı denedik. Ay'ı ne şekilde karartacağımız ile ilgili şekiller gelişstirdik" biçiminde görüş bildirmişlerdir.

Gruplardan görev alan öğretmen adaylarının 17'si animasyonun oluşturma aşamasında genel anlamda eleştirel düşünme ve problem çözme becerilerini kullandıklarını ifade etmişlerdir. Gruplardan G3 "Kurbağaların dönemsel özelliklerini gösterecek fotoğraflarını resmetmede zorlandık yardım alarak (internet, resimler bu problemi de çözmeyi başardık. Animasyonda sürekliliği sağlamak içinse fotoğraf çektik. Fakat çekerken resimler kayıyordu. Ama düşündük bunu en aza indirecek şekilde nasıl yaparız diye ve yapmayı başardık". G19 "Bu basamakta kartonlarla gün ışıklarında ani geçişler de zorlandık. Ana tonları kullanmaya çalışarak durumu çözmeye çalıştık. Kartonlarla istediğimiz aksiyonu oluşturamadığımız için bu basamakta renkli çıktılardan yararlandık. Fotoğraflama da en zoru kaydırmamaktı. Sabitlemek 
için masaya koyduk ama olmadı. En sonunda kendimize kartonda sınır belirleyip o şekilde kaydırmayı en aza indirmeye çalıştık." biçiminde görüş bildirmişlerdir. Gruplardan görev alan öğretmen adaylarının tamamının genel anlamda grup üyeleriyle sürekli iletişim ve işbirliği içinde oldukları belirlenmiştir. Gruplardan G3 "Tüm aşamalarda bir araya gelerek beyin fırtınası tekniğini kullandık. Birbirimize fikirlerimizi sözlü olarak ilettik. Ayrıca animasyon bitmiş halini facebook ortamına kullanarak yayınladık ve internet ortamından da iletişim kurduk". G5 "Resimleri hepimiz çizdik. Fotoğraf çekerken grup olarak toplandık ve çekimi bitirdik. Ses kaydında da üçümüzün de sesi var. Raporumuzu birlikte yazdık. Kısacası her aşamasında grup olarak hareket ettik. İşbirliğimiz iyiydi" biçiminde görüş bildirmişlerdir.

Grupların tamamında öğretmen adaylarının genel anlamda iletişim ve işbirliği becerilerini kullanmalarına rağmen esneklik ve uyum becerilerini kullandıklarını gösteren ifadeler kullanmadıkları görülmüştür. Gruplardan ikisinde görev alan öğretmen adayları animasyonun oluşturma aşamasında kendi becerilerinin sınırlarını aşarak kendi öğrenme sınırlarını keşfetmelerini sağlayacak, becerilerini profesyonel düzeye yükseltecek bilgiye ulaşmaları için "girişim ve özyönetim" becerilerini kullandıkları belirlenmiştir. Gruplardan G8 "Slowmation uygulamasını yapabileceğimiz programları araştırdık. Sonuçta anlaşılması uygulanması kolay olan Windows movie maker programı hakkında detaylı bilgi edindik." biçiminde görüş bildirmiştir. Öğretmen adaylarının oluşturma aşamasında da " sosyal ve kültürlerarası beceriler " ve " liderlik ve sorumluluk" becerilerini kullandıklarını gösteren ifadeler kullanmadıkları belirlenmiştir. Gruplardan 12 sinde yer alan öğretmen adaylarının oluşturma aşamasında modellerin ve sonrasında fotoğrafların boyutlarını ve karar verme, bilgi eksikliğini hissettikleri bölümlerde farklı kaynaklara yönelerek "bilgi okuryazarlığı" becerilerini işe koştukları görülmektedir. Gruplardan G1 "Slowmation da fotoğrafların boyutunu ayarlayabilmek için uygun fotoğraf formatının hangisi olduğu araştırıldı.", G21" Modellerin fotoğraflandırımasını yaparken şekil boyutları ve konumu ayrıca çekim uzaklığı internetten takip edildi, o şekilde fotoğraflandırma yapıldı" biçiminde görüş bildirmişlerdir. Gruplardan G21 "Windows movie maker ve slowmation görüntüleri modellerin fotoğraflandırıması yapılırken you tube gibi sitelerden örnek olması için izlendi", G22 "Konu hakkında bilgi edindikten sonra görsel kaynaklar taradık. Video bulduk onlar arasından eleme yaptık. Bizim yansıtmak istediğimiz aktarmak istediğimiz durumu aktaran en uygun görseli model olarak aldık. Görsellerde farklı materyaller kullanılmıştı ancak biz ilgi çekici ve canlı görünmesi için oyun hamuru ve siyah karton kullandık" biçiminde görüş bildirerek oluşturma aşamasında sınırlı düzeyde "Medya Okuryazarlığı" becerisini kullandıklarını belirtmişlerdir. Gruplardan G3 "Resimleri çekerken teknoloji ürünü olan fotoğraf makinesini kullandık. Işık için masa lambasını kullandık. Resimleri bilgisayar ortamında movie maker programını kullanarak birleştirdik. Ses kaydı için bilgisayar ortamında ses kaydedici programını kullandık. Ayrıca efekt sesleri içinde yabancı bir siteden faydalandık" biçiminde görüş bildirerek "Bilgi ve Iletişim Teknolojileri Yeterliği" becerisini kullandıklarını belirtmişlerdir.

Tablo 3 incelendiğinde, öğretmen adaylarının çekilen fotoğrafları ve ses kayıtlarını bir düzen haline getirerek ilgili programa yükledikleri yeniden oluşturma aşamasında, yaratıcılık ve yenilenme, eleştirel düşünme ve problem çözme, işbirliği ve iletişim ile bilgi ve iletişim teknolojilerine ilişkin yeteneklerini kullandıkları belirlenmiştir. Grupların 18'i yeniden oluşturma aşamasında farklı teknikleri, görsellerin veya ses efektlerini kullanarak yaratıcılıklarını kullandıklarını belirtmişlerdir. Gruplardan G1 "Slowmationumuzun başına ve sonuna jenerik hazırlanmasına ve daktilo sesinin kullanılarak konu başlıklarının böyle yazılmasını sağladık." G5 "Başlangıçta izleyenlerin dikkatini çekebilme amacıyla farklı bir video koyduk ve devamında fonda kurbağa sesleri ile döngünün seslendirmesini gerçekleştirdik." G24 "Animasyon oluştururken iki farklı durumu ayırt etmek amacıyla birçok farklı ses kullandık." biçiminde görüşlerini belirtmişlerdir. Grupların 12'si genel anlamda eleştirel düşünme ve 
problem çözme becerilerini kullandıklarını ifade etmişlerdir. Gruplardan G3 "Yaptığımız animasyonun bitirilmiş halini izlerken de hedef kitleye uygunluğunu yaptığımız hataları eleştirel bir şekilde düşünüp gözlemleyerek düzeltmeye çalıştık." G10 "Fotoğrafların aktarılması, zaman çizelgesinin yapılmasını müziğin konulmasında eleştirel düşündük ve çözüme ulaştık." biçiminde görüşlerini belirtmişlerdir.

Gruplardan görev alan öğretmen adaylarının tamamının grup üyeleriyle sürekli iletişim ve işbirliği içinde oldukları belirlenmiştir. Gruplardan G9 " Kararlarımızı birlikte konuşarak verdik.", G13 "Grup arkadaşlarımızla her aşamada düşüncelerimizi paylaşarak bir karara vardık." biçiminde görüşlerini belirtmişlerdir. Grupların "esneklik ve uyum becerilerini ", "girişim ve özyönetim" , "sosyal ve kültürlerarası beceriler" ve "liderlik ve sorumluluk" becerilerini kullandıklarını gösteren ifadeler kullanmadıkları belirlenmiştir.

Gruplardan 12'sinde yer alan öğretmen adaylarının yeniden oluşturma aşamasında fotoğrafların programa aktarılması, birleştirilmesi ses efektlerin eklenmesi konusunda araştırma yapmaya yönelerek "bilgi okuryazarlığı" becerilerini işe koştukları görülmektedir. Gruplardan G23 "Grubumuzda Movie Maker programını kullanabilen kimsenin olmayışı bir problem oluşturdu. Daha sonra programın kullanımını anlatan bir video izledik ve programı hedeflerimiz doğrultusunda kullandık." biçiminde görüş bildirmişlerdir. Gruplardan G2 "Elde edilen verileri sıraya dizdik ve sürelerini ayarladık. Bu şekilde animasyonları oluşturduk.", G10 "Oluşturduğumuz modele göre fotoğraflarımızı sıraladık ve movie maker programıyla animasyonumuzu oluşturduk." biçiminde görüş bildirerek yeniden oluşturma aşamasında "Bilgi ve Illetişim Teknolojileri Yeterliği" becerisini kullandıklarını belirtmişlerdir.

\section{2. Öğrenme alanlarına göre YGA'ların yeterlik durumlarına ilişkin bulgular}

Oluşturulan YGA'lar hikâyenin oluşturulması, görselleştirilmesi, kameranın çalışması, karakterler ve rolleri, senaryo (kurgu), ürün değeri ve fen içerik bilgisini içerme durumlarına göre değerlendirilmiştir. Her üç araştırmacı tarafından grupların aldıkları puanların ortalamaları Tablo 4'te karşılaştırmalı olarak verilmiştir.

Tablo 4

YGA'ların Dereceli Puanlama Anahtarına Göre Değerlendirme Puanları

\begin{tabular}{|c|c|c|c|c|c|c|}
\hline & $\begin{array}{l}\text { Yavaş Geçişli Animasyon } \\
\text { Konuları }\end{array}$ & $\frac{\frac{\pi}{E}}{\frac{\pi}{\frac{\pi}{\pi}}}$ & 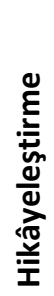 & 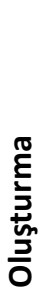 & 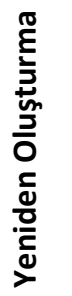 & $\frac{\frac{E}{\pi}}{\frac{0}{0}}$ \\
\hline \multirow{8}{*}{ 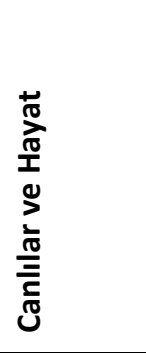 } & 1. Çimlenme-1 & 4 & 4 & 3 & 3 & 14 \\
\hline & 2. Çimlenme-2 & 2 & 2 & 2 & 1 & 7 \\
\hline & 3. Canlıların Yaşam Döngüsü & 3 & 3 & 2 & 2 & 10 \\
\hline & 4. Kelebeğin Yaşam Döngüsü & 3 & 4 & 3 & 2 & 12 \\
\hline & 5. Mayalanma-1 & 2 & 2 & 1 & 1 & 6 \\
\hline & 6. Mayalanma-2 & 3 & 3 & 2 & 1 & 9 \\
\hline & 7. Mayoz Bölünme & 3 & 3 & 2 & 2 & 10 \\
\hline & 8. Su Döngüsü & 4 & 4 & 2 & 3 & 13 \\
\hline \multirow{4}{*}{ 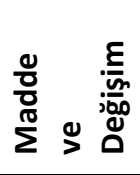 } & 9. Maddenin Hal Değiş̧imi-1 & 2 & 2 & 1 & 1 & 6 \\
\hline & 10. Maddenin Hal Değişimi-2 & 2 & 1 & 2 & 1 & 6 \\
\hline & 11. Karışımları Ayırma -1 & 2 & 2 & 2 & 1 & 7 \\
\hline & 12. Karışımları Ayırma -2 & 3 & 3 & 2 & 2 & 10 \\
\hline
\end{tabular}




\begin{tabular}{|c|c|c|c|c|c|c|}
\hline & 13. Geri Dönüşüm & 5 & 5 & 4 & 5 & 19 \\
\hline \multirow{3}{*}{ 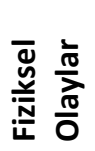 } & 14. Elektriklenme-1 & 3 & 4 & 3 & 4 & 14 \\
\hline & 15. Elektriklenme-2 & 3 & 4 & 4 & 4 & 15 \\
\hline & 16. Yıldırım ve Şimşek & 5 & 4 & 4 & 4 & 17 \\
\hline \multirow{9}{*}{ 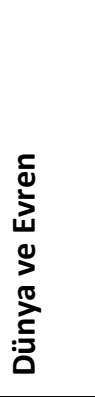 } & 17. Ayın Evreleri -1 & 2 & 3 & 2 & 2 & 9 \\
\hline & 18. Ayın Evreleri -2 & 2 & 2 & 2 & 2 & 8 \\
\hline & 19. Ayın Evreleri -3 & 2 & 2 & 3 & 1 & 8 \\
\hline & 20. Gece ve Gündüz Oluşumu -1 & 2 & 2 & 2 & 1 & 7 \\
\hline & 21. Gece ve Gündüz Oluşumu -2 & 4 & 4 & 3 & 4 & 15 \\
\hline & 22. Güneş Tutulması & 2 & 2 & 2 & 2 & 8 \\
\hline & 23. Mevsimlerin Oluşumu-1 & 3 & 2 & 2 & 2 & 9 \\
\hline & 24. Mevsimlerin Oluşumu-2 & 3 & 4 & 3 & 3 & 13 \\
\hline & Kategorilerin Ortalama & 2.8 & 2.9 & 2.4 & 2.2 & \\
\hline
\end{tabular}

Oluşturan dereceli puanlama anahtarına göre alınacak maksimum puan 20 olarak belirlenmiştir. Tablo 4'e göre öğretmen adaylarının oluşturdukları animasyonlar değerlendirildiğinde toplam puana göre en başarılı olanı "Madde ve Değişim" öğrenme alanında oluşturulan "Geri Dönüşüm" animasyonudur. "Madde Değişim" öğrenme alanında oluşturulan dördü ortalamanın altında puan alarak başarısız olarak değerlendirilirken, bir animasyon (Geri Dönüşüm) tam puana yakın bir puanla değerlendirilmiştir. Bu öğrenme alanında "Geri Dönüşüm" konusu dışında oluşturulan tüm animasyonlarda özellikle fen içerik bilgisi bağlamında öğrencilerin eksik olduğu söylenebilir. Diğer değerlendirme kategorilerinde de öğrencilerin içerik bilgisinde olduğu gibi eksikliklerin olduğu, eksik içerik bilgisini diğer alanlarda da sürdürdükleri belirlenmiştir. Oluşturulan "Geri Dönüşüm" YGA'da Fen içerik bilgisi animasyonda ekli bir senaryo (kurgu) ile verilmiştir. Fotoğraf makinesi tek açıdan görselleştirmesine rağmen, karakterle üç boyutlu olarak yapılandırılmış ve uygun materyaller kullanılarak konu etkili bir biçimde aktarılmıştır.

"Fiziksel Olaylar" öğrenme alanında oluşturulan animasyonların üçünde de fen içerik bilgisi ortalama bir düzeyde animasyona aktarılmıştır. Her üç animasyonda da hikâyeleştirme ortalama bir puan alırken, hikâyenin görselleştirilmesinde başarılı kabul edilebilirler. Ürün değeri açısından kullanılan malzemelerin konuya ve amaca uygun olması açısından başarılı olarak değerlendirilmişlerdir. Bu öğrenme alanında öğrencilerin daha fazla başarılı ürün sergilemelerinin bir nedeni öğrencilerin yaşadıkları çevreye ve dünyaya ilişkin algılarının ve deneyimlerin fazla olması ile açıklanabilir. Görselleştirmese de ve diğer oluşturma aşamalarında çok fazla zorlanmadıkları değerlendirme puanlarından anlaşılmaktadır. "Fiziksel Olaylar" öğrenme alanında oluşturulan her üç animasyonda ortalamanın üzerinde puan alarak başarılı olarak değerlendirilmiştir. Bu öğrenme alanında en yüksek puanı alan "Yıldırım ve Şimşek" YGA'nun da fen içerik bilgisi etkili bir biçimde aktarılmıştır. Aynı zamanda ürün değeri, senaryo ve görselleştirme bu alanda oluşturulmuş diğer animasyonlarda olduğu gibi oldukça iyidir.

"Canlılar ve Hayat" öğrenme alanında oluşturulan sekiz animasyondan dördü başarılı olarak değerlendirilmiştir. "Çimlenme-1" YGA' nu bu alanda en başarılı animasyon olarak değerlendirilmiştir. Fen içerik bilgisi ve görselleştirilme oldukça iyidir. Ancak fotoğraf makinesinin kullanımı konusunda bütün animasyonlarda olduğu gibi burada da eksiklik belirlenmiştir. Genel anlamda başarılı olarak değerlendirilen animasyonlarda içerik bilgisinin verildiği ancak senaryolaştırma da sıkıntıların olduğu söylenebilir. Ürün değeri anlamında uygun materyallerin kullanıldığını söyleyebiliriz.

"Dünya ve Evren" öğrenme alanında oluşturulan sekiz animasyondan sadece ikisi (Gece ve Gündüz Oluşumu-2, Mevsimlerin Oluşumu-2) ortalamanın üstünde puan alarak 
yeterli olarak değerlendirilirken diğer animasyonların belirlenen ölçütlere göre yeterli olmadıkları sonucuna ulaşılmıştır.

\section{SONUÇ, TARTIŞMA VE ÖNERILER}

Fen ve Teknoloji Öğretimi II dersi kapsamında sınıf öğretmeni adaylarının yavaş geçişli animasyon oluşturma sürecinde, 21. yüzyıl becerilerinin farklı boyutlarını farklı aşamalarda ağırlıklı olarak ya da sınırlı düzeyde kullandıkları belirlenmiştir. Araştırmada öğretmen adaylarının, bilginin farklı kaynaklardan araştırılarak yapılandırıldığı planlama aşamasında yaratıcılık ve yenilenme becerisini kullanmadıkları ancak diğer aşamalarda sınırlıda olsa bu beceriyi kullandıkları sonucuna ulaşımıştır. Yapılandırmacı yaklaşımın öğretim programlarında kullanıldığı düşünüldüğünde öğretmen adaylarının bu anlamda bilginin yapılandırması için yaratıcılıklarını kullanmadıkları ancak yapılandırılmış bilginin hikâyeye, modele ve animasyona dönüştürülmesi konusunda yaratıcılıklarını kullandıkları görülmüştür. Araştırmanın tüm aşamalarında öğretmen adaylarının eleştirel düşünme ve problem çözme becerilerini kullandıkları belirlenmiştir. Araştırmanın bu bulgusu farklı araştırmaların teknoloji kullanımının akıl yürütme, karar verme gibi karmaşık düşünme becerilerinin kullanımını sağladığı ve geliştirdiği (Afshari ve diğerleri, 2009; Rakes, Fields ve Cox, 2006) bulgusu ile örtüşmektedir.

Araştırmada öğretmen adaylarının her aşamada işbirliği ve iletişim becerilerini işe koştukları ve sürecin aşamalarında gelişme gösterdikleri belirlenmiştir. Araştırmada elde edilen bu bulgu, Hoban ve Nielsen'ın (2012) yaptığı araştırmada, öğretmen adaylarının yavaş geçişli animasyon oluşturma sürecinin ve ürünlerin sunumunun sosyal bir etkileşim içinde olmalarına olanak sağlanmış olması sonucu ile örtüşmektedir. Bunun yanın sıra Brown, Murcia ve Hackling (2013) yavaş geçişli animasyon gibi teknolojinin çok yönlü kullanıldığı uygulamaların, öğrencilerin işbirliği içinde çalışma kurallarına uydukları ve işbirliği içinde çalışmalarını geliştirdikleri sonucu da araştırma bulgularını desteklemektedir. Öğretmen adaylarının planlama aşamasında yaratıcılıklarını kullanmazken sürecin ilerleyen aşamalarında işbirliği ve iletişim becerilerindeki artışla birlikte yaratıcılık ve yenilenme becerilerini de işe koştukları belirlenmiştir. Araştırmanın bu bulgusu Biriş̧i ve Karal'ın (2011) öğretmen adaylarının bilgisayar destekli ortamda materyal tasarlarken işbirliği içinde çalışmalarının, yaratıcı düşünme becerilerine etkisinin belirlenmesini amaçlayan araştırmasında, öğretmen adaylarının yaratıcılıklarının gelişsmesinde işbirliği içinde çalışmalarının etkili olduğu sonucu ile örtüşmektedir. Arnold, Padilla ve Tunhikorn'un (2009) yaptıkları araştırmada öğretmen adaylarının süreçte bilgi teknolojilerini kullanmaları, onların yaratıcılıklarına, grup içinde işbirliğine dayalı olarak katılım sağlamalarına, soru sormada kendilerini rahat hissettikleri, düşündüklerini yansıtabildikleri ve tartışabildikleri bir ortamın olduğu sonucu, araştırma bulgularını desteklemektedir. Araştırmada, uygulamanın öğrencilerin grup içinde birbirlerine soru sormada, arkadaşlarıyla iletişimde ve işbirliği içinde çalışmalarına ve yaratıcılıklarına katkı sağladığını, uygun bir ortam ve süreç oluşturduğunu ifade etmek mümkündür. Hayes (2003) yaptığı araştırmada, video oluşturma sürecinin öğretmen adayları arasında işbirliğini teşvik ettiği, eleştirel düşünme becerilerini geliştirdiği yaratıcı olmalarını teşvik ettiği ve keyifli bir öğrenme deneyimi yaşattığı sonucu da araştırma bulgularını desteklemektedir

Öğretmen adaylarının planlama, hikâyeleştirme ve oluşturma aşamalarında bilgi okuryazarlığı, medya okuryazarlığı ve bilgi ve iletişim teknolojileri yeterliği anlamında becerilerini kullandıkları ancak yeniden oluşturma aşamasında bu becerileri kullanmadıkları belirlenmiştir. Öğretmen adaylarının bilgi ve iletişim teknolojileri yeterliğini yeniden oluşturma sürecinde de kullandıkları sonucuna ulaşıımıştır. Brown, Murcia ve Hackling (2013) yavaş geçişli animasyon ile hazırlanmış kasıtlı öğrenme- öğretme durumu, öğrencilere eğlenceli bir fen eğitimi sağlarken aynı zamanda onların bilimsel okuryazarlıklarının gelişmesini de katkı sağladığı sonucu araştırma sonuçlarıyla paralellik göstermektedir. Kidman (2015) 
araştırmasında sorgulamaya dayalı dönüşümsel öğrenme kuramına dayandırdığı yavaş geçişli animasyon uygulaması ile öğretmen adaylarının deneyimleri ile bilişsel yapılarının farkına vararak kendilerini tanımalarına ayrıca üst düzey düşünme kavramları ile tanışmaların bu uygulama ile mümkün olduğu sonucu araştırma sonuçlarını desteklemektedir. Slowmation oluşturmanın en yararlı özelliği öğretmen adaylarının bilgilerini sunabildikleri dijital yapay ürünlerini kendi teknolojilerini kullanarak yapabilmeleridir. Bu teknolojiyi kendi tripotları üzerine yerleştirerek sabitledikleri kameraları ve mevcut video yapım programı oluşturur Araştırmadan elde edilen bu bulgu daha önce yapılan çalışma sonuçları ile örtüşmektedir (Chang, Quintana, C. ve Krajcik, 2010; Hubscher-Younger \& Hari Narayanan, 2008; Kidman, 2015; Schank \& Kozma, 2002).

Öğretmen adaylarının günlük yaşamda karşılaşılan (geri dönüşüm, gece ve gündüz oluşumu, yıldırım ve şimşek, çimlenme gibi) konulara yönelik oluşturdukları animasyonlarda yeterliklerinin daha iyi olduğu görülmektedir. Bu bağlamda düşünüldüğünde yeteri kadar bilgi sahibi oldukları konularda öğrencilerin somut bir biçimde bu bilgilerini gösterebilmeleri, bir ürün ortaya koyabilmeleri için yaşamda bu durumlarla karşılaşmaları gerektiği söylenebilir. Öğretmen adaylarının bilgilerini yapılandırdıkları planlama aşamasında yeterliklerinin iyi olmasına rağmen, bilgilerini hikâyeye dönüştürme, model oluşturma ve bu modellerin fotoğraflandırarak programa aktarıldığı diğer aşamalarda yeterliklerinin pek de iyi olmadığı belirlenmiştir. Bu bağlamda 2004 te öğretim programlarına giren yapılandırmacı yaklaşım ile yetişen öğretmen adaylarının bilgiyi yapılandırmalarında sorun yaşamadıkları ancak bilginin farklı şekilde ifade etme ve ürün ortaya çıkarma anlamında yeterli olmadıkları söylenebilir. Öğretim programlarına yeni yeni uyarlanabilen yapılandırmacı yaklaşımın bu bağlamda eksikliklerinin olduğunu söylenebilir. Bu bağlamda Fen ve Teknoloji Öğretimi dersinin içeriği yavaş geçişli animasyon (slowmation) uygulaması ile zenginleştirilebilir. Uygulama sonunda öğretmen adayları derslerinde kullanabilecekleri yaratıcılığın ve öğrenciler arasında işbölümünün gerektirdiği yeni bir öğretim yaklaşımına yönelik deneyim kazanmışlardır. Bu bağlamda öğretmen adaylarının öğretmenlik uygulamasını gerçekleştirecekleri sınıflarında animasyon hazırlayıp veya var olan animasyonları öğrencileriyle paylaşarak derslerini planlayabilmeleri sağlanabilir.

\section{KAYNAKLAR}

Afshari, M., Bakar, K.,A., Luan, W.,S., Samah, B.A. \& Fooi, F.,S. (2009). Factors affecting teachers' use of information and communication technology. International Journal of Instruction, 1 (2), 77-104.

Arnold, S.R., Padilla, M, J. ve Tunhikorn, B. (2009). The development of pre-service science teacher's professional knowledge in utilizing ICT to support professional lives. Eurasia Journal of Mathematics, Science\&Technology Education, 5(2), 91-101.

Atalay, N. (2015). Fen bilimleri dersinde öğrencilerin öğrenme ve yenilenme becerilerinin gelişiminde yavaş geçişli animasyon( slowmation) uygulaması. Yayınlanmamış Doktora Tezi, Anadolu Üniversitesi, Eskişehir.

Atılboz, N. G. (2004). Lise 1. Sınıf öğrencilerinin mitoz ve mayoz bölünme konuları ile ilgili anlama düzeyleri ve kavram yanılgıları. Gazi Üniversitesi Eğitim Fakültesi Dergisi, 24 (3), 147-157.

Biriş̧i, S. ve Karal, H. (2011). Öğretmen adaylarının bilgisayar destekli ortamda materyal tasarlarken işbirlikli çalışmalarının yaratıcı düşünme becerilerine etkisi. Ahi Evran Üniversitesi Eğitim Fakültesi Dergisi, 12 (2), 203-219 
Brown, J. (2011).The impact of student created slowmation on the teaching and learning of primary science. (Yayımlanmamış Yüksek Lisans Tezi). University of Edith Cowan, Australia.

Brown, J., Murcia, K. ve Hackling, M. (2013). Slowmation: A multimodal strategy for engaging children with primary science. Teaching Science, 59 (4), 14-20.

Chang, H., Quintana, C., \& Krajcik, J.S. (2010). The impact of designing and evaluating molecular animations on how well middle school students understand the particulate nature of matter. Science Education, 94, $73-94$

Czarnecki, K. (2009). How digital storytelling builds 21st century skills. Tam metni www.alatechsource.org (Erişim Tarihi: 2013, 10 Ekim)

Darling- Hammond, L. ( 1995). Promising practices in teacher accrediation and standarts. In Marlaine E. Lockheed (Eds). Module training: Decentralization in education. World Bank Resources Sector Professional Week Papers, Washington, DC.

Dede, C. (2010). Comparing Frameworks for 21st Century skills. 21st Century skills. http://watertown.k12.ma.us/dept/ed tech/research/pdf/ChrisDede.pdf (Erişim Tarihi: 2014, 3 Nisan)

Ekici, E ve Ekici, F (2011). Fen eğitiminde bilişim teknolojilerinden faydalanmanın yeni ve etkili bir yolu: "yavaş geçişli animasyonlar. Illköğretim Online, 10(2), 1-9.

Ersoy, A. (2006). İlköğretim beşinci sınıfta teknoloji destekli proje tabanlı öğrenme uygulamaları. Yayınlanmamış doktora tezi. Eskişehir: Anadolu Üniversitesi Eğitim Bilimleri Enstitüsü.

Hayes, M.T. (2003). The pleasure of movie making. Journal of Computing in Teacher Education, $19(3), 82-86$

Hoban, G. (2005). From claymation to slowmation: A teaching procedure to develop students' science understandings. Teaching Science: Australian Science Teachers Journal, 51(2), 26-30.

Hoban, G. ve Ferry, B. (2006). Teaching science concepts in higher education classes with slow motion animation (slowmation). Paper presented at the E-Learn 2006 World Conference on ELearning in Corporate, Government, Healthcare \& Higher Education, Honolulu, Hawaii. www.editlib.org

Hoban, G. (2007). Using slowmation to engage preservice elementary teachers in understanding science content knowledge. Contemporary Issues in Technology and Teacher Education, 7(2), 1-9.

Hoban, G. (2009). Facilitating learner-generated animations with slowmation. In L. Lockyer, S. Bennett, S. Agostino \& B. Harper (Eds.), Handbook of Research on Learning Design and Learning Objects: Issues, Applications, and Technologies (pp. 313-330). Hershey, PA: IGI Global

Hoban, N. ve Nielsen, W. (2010). The 5 Rs: A new teaching approach to encourage slowmations (studentgenerated animations) of science concepts. Teaching Science, 56(3), 33-37

Hoban, G.ve Nielsen, W. (2012). Learning science through Creating a 'Slowmation': A case study of preservice primary teachers. International Journal of Science Education, 1-28.

Hubscher-Younger, T., \& Hari Narayanan, N. (2008). Turning the tables: Investigating characteristics and efficacy of student-authored animations and multimedia. In R. Lowe \& W. 
Schnotz (Eds.), Learning with animation: Research implications for design (pp. 235 - 259). New York, NY: Cambridge University.

Keast, S., Cooper, R., Berry, A., Loughran, J. \& Hoban, G., 2010, Slowmation as a pedagogical scaffolding for improving science teaching and learning. International Journal of Science and Mathematics, 2(1),1-15.

Kervin, K. (2007), Exploring the use of slow motion animation (slowmation) as a teaching strategy to develop year 4 students' understandings of equivalent fractions. Contemporary Issues in Technology and Teacher Education, 7(2), 100-106.

Kidman, G. (2015). Faciliating meta-learning in preservice teachers: using integration and slowmation animation. Procedia - Social and Behavioral Sciences, 167, 117- 123.

Köseoğlu, P., Yılmaz, M., Gerçek, C. ve Soran, H. (2007). Bilgisayar kursunun bilgisayara yönelik başarı, tutum ve öz-yeterlik inançları üzerine etkisi. Hacettepe Üniversitesi Eğitim Fakültesi Dergisi, 33, 203-209

Laybourne, K. (1998). The animation book. New York: Three Rivers Press.

Miles, M.B. ve Huberman, A.M. (1994). Qualitative data analysis. Newbury Park, CA: Sage.

Olkun, S. ve Toluk, Z. (2003). Illköğretim etkinlik temelli matematik öğretimi. Ankara: Anı Yayıncilık

Organisation for Economic Co-operation and Development. (OECD). (2009). 21 st century skills and competences for new millennium learners in OECD countries. Education Working Papers, 41

Ochsner, K.(2010). Lights, camera, action research: the effects of didactic digital movie making on students' twenty-first century learning skills and science content in the middle school classroom. (Yayımlanmamış Doktora Tezi). University of Arizona State, Arizona.

Partnership for 21st Century Skills. (2009) Framework for 21st century learning. http://www.p21.org/our-work/p21-framework (Erişim Tarihi: 2013, 12 Ekim).

Rakes, G.C., Fields, V.S., \& Cox, K.E. (2006). The influence of teachers' technology use on instructional practices. Journal of Research on Technology in Education, 38 (4), 411-426.

Schank, P. ve Kozma, R. (2002). Learning chemistry through the use of a representation-based

knowledge building environment. Journal of Computers in Mathematics and Science Teaching, $21,253-279$.

Seferoglu, S. S., Akbıyık, C. ve Bulut, M. (2008). Ilköğretim öğretmenlerinin ve öğretmen adaylarının bilgisayarların öğrenme/öğretme sürecinde kullanımı ile ilgili görüşleri. Hacettepe Üniversitesi Eğitim Fakültesi Dergisi, 35, 273-283.

Songer, N.B. (2007). Digital resources versus cognitive tools: A discussion of learning science with technology, In S. K. Abell \& N. G. Lederman (Eds.), Handbook of Research on Science EducationMahwah, NJ. Lawrence Erlbaum.

Wagner, T. (2008b). Rigor redefined. Educational Leadership, 68 (2), 20-24.

Vratulis,V., Clarke, T., Hoban, G. ve Erickson, G.(2011). Additive and

disruptive pedagogies: The use of slowmation as an example of digital technology implementation. Teaching and Teacher Education, 27(8), 1179-1188 
Fen Öğretiminde Teknoloji Entegrasyonunun 21. Yüzyıl Becerileri Boyutunda Değerlendirilmesi: Yavaş Geçişli Animasyon Uygulaması

Nurhan ATALAY - Şengül S. ANAGÜN - Evrim GENÇ KUMTEPE

Yıldırım, A. ve Şimşek, H. (2005). Sosyal bilimlerde nitel araştırma yöntemleri. Ankara: Seçkin Yayıncılık.

Yin, R. Y. (2003). Case study research: Design and methods. ThousandOaks: Sage Publication. 


\section{SUMMARY}

The rapid development of Information and Communication Technology (ICT) has mandated a change and transformation in every area of life. In information age, individuals are expected; to adapt themselves to the changes and continue their lives, to follow the technology, to select, analyze and evaluate the required information among the piles of information that are produced and spread quickly, to be able to use the obtained information in their daily life, and to transform this information into a product. In addition of using basic skills, individuals should possess and use high level skills and capabilities as well.

These skills and capabilities that the individuals of information society should have are called as the $21^{\text {st }}$ century skills. $21^{\text {st }}$ century skills, where the knowledge and skills are used in conjunction, are the skills enabling individuals; to live their lives in a more qualified manner, to solve the problems they face more easily, to analyze events occurring around them or in the community by looking from different perspectives, to be more successful in their professional and social life. Individuals may acquire $21^{\text {st }}$ century skills, which are classified as learning and renewal, life and career, information, media and technology skills or under other headings, in all steps of the education, from primary school to high education, through training.

There are many application areas where the impacts of technologic developments are observed, education is one of the most common application areas. Teachers who bring technology in education environment, allowing students to use the technology in learning-teaching process, should have these capabilities. The main objective of teacher education institutions is teaching new approaches and techniques that are used in learning-teaching process to teacher candidates, enabling them to implement these approaches in their own classes during their practices. With slowmation, students attempt to get access to information by using technology interactively within a group and run their thinking skills in the process. Based on the "individuals construct the knowledge by themselves" principle of constructivist approach, this method allows students to follow a process where they use various thinking skills and the teacher acts as a guide, for accessing to information. It aims to develop the student by using these thinking skills through this process, while they access to information and create a product.

The purpose of this research is revealing the capabilities of classroom teacher candidates in using different dimensions of $21^{\text {st }}$ century skills and assessing the animations prepared through the slowmation creation process according to defined criteria. The participants of the study were composed of 100 junior students including 16 males and 84 females at a Mid-Western University of Turkey. The research has two main criteria which are 1) voluntarily participation and 2) attending to $3^{\text {rd }}$ grade, considering that science and technology lab and other basic science courses are taken and completed at this level. The application was carried out with classroom teacher candidates, during Science and Technology Instruction II course, in 10 weeks. Before the application, researchers have informed teacher candidates about slowmation creation process and Movie Maker software that is used in this process, for six hours. Students have formed groups of 4-5 people according to their own preferences. Each group picked a topic among the learning areas of primary education science curriculum, namely "organisms and life", "matter and change", "physical events", "the earth and the universe" and they created a total of 24 slowmation. The data were collected through an open-ended questionnaire developed by the authors and validated by the field experts and students' learning artifacts. In the study, embedded single-case design, which is one of the designs of case study, was used. Qualitative data were collected in writing and analyzed using descriptive analysis technique.

According to the result of the study, it was found that in planning stage teacher candidates have used all $21^{\text {st }}$ century skills except "creativity and innovation" and "entrepreneurship and selfmanagement". The assessment of the animations created by teacher candidates according to the defined criteria showed that slowmations created in "physical Events" learning area were the most adequate ones. The remaining SMAs, except the ones prepared for "Recycling" topic of "Matter and Change" learning area, were found to be insufficient when evaluated according to the creation criteria.

It has been found that classroom teacher candidates have used various dimensions of $21^{\text {st }}$ century skills in different stages of slowmation creation process. It was observed that teacher candidates have not used "creativity and innovation" in the planning stage, which comprises information collection through the investigation of different resources, however they have used this skill in the other stages, although it was limited. It was found that teacher candidates have used critical 
thinking and problem solving skills in all stages of the research. This finding overlaps with the finding of other researches indicating that the use of technology promotes and improves complex thinking skills, such as reasoning and decision making (Afshari et al., 2009; Rakes, Fields and Cox, 2006). It has been observed that teacher candidates have used cooperation and communication skills in all stages of their work and they have shown progress in the subsequent stages of the process. This finding overlap with the results of Hoban and Nielsen's (2012) research, indicating that slowmation creation process and the presentation of the products have allowed teacher candidates to be in a social interaction. It was found that teacher candidates have used information literacy, media literacy, and information and communication technology competency skills in planning, narration and development stages, however they have not used them in recreation stage. The result of the research is parallel to the finding of Brown, Murcia and Hackling (2013), indicating that intentional learning-teaching conditions prepared through slowmation make contribution to the development of students' scientific literacy, while providing them an entertaining science education. 